\title{
PECULIARITIES OF COLLECTION AND CRYOPRESERVATION OF STALLION SPERM
}

\author{
O. V. MYHOVYCH, Veterinarian \\ Zhashkiv Equestrian School, Zhashkiv, Ukraine \\ Yu. S. MASALOVICH, Assistant
}

Department of Obstetrics, Gynecology and Biotechnology of Animal Reproduction https://orcid.org/0000-0002-0986-0854

National University of Life and Environmental Sciences of Ukraine, Kyiv, Ukraine

O. A. VALCHUK, Candidate of Veterinary Sciences, Head of the Department

of Obstetrics, Gynecology and Biotechnology of Animal Reproduction, https://orcid.org/0000-0002-4178-0352

National University of Life and Environmental Sciences of Ukraine, Kyiv, Ukraine

E-mail: masalovich@nubip.edu.ua

\begin{abstract}
Horse breeding in Ukraine has always been an industry of national importance, the functional orientation of which has changed because of the development of socioeconomic relations. Currently, the role and importance of horses in state farms is complex nature. Breeding horses are used to improve existing and create new, more advanced breeds that would meet the requirements of European and world standards.

Improving the efficiency of reproduction technologies in horse breeding and further progress of breeds is impossible without the implementation of methods of artificial insemination of horses, including cryopreservation of sperm.

Multiple improvements have been achieved in the past 10 years with regard to utilization and processing of frozen stallion semen, use of alternative cryoprotectors and new commercially available extenders that allow better cell protection during freezing.

It is analyzed that there is only one licensed cryogenic sperm bank of certified sports stallions in Ukraine, which is located in Zhashkiv Equestrian School, from where sperm is transported abroad. It contributes to the improvement of the existing gene pool of horses in our country and promotes the industry. The technological process of selection and cryopreservation of sperm in breeding stallions of the Belgian sport breed in the Zhashkiv Equestrian School of Cherkasy region is investigated. The latest methods for selection and cryopreservation of stallion sperm are presented. It has been investigated that cryopreservation using pre-cooling of sperm for $2.5 \mathrm{~h}$ and subsequent rapid freezing in liquid nitrogen vapors is an effective method for maintaining the fertilizing ability of stallions. It is established that following the above rules of selection, evaluation, calculation, dilution, packaging, cryopreservation, and storage of sperm of high-value stallions, the number of sperm banks might be increased. This popularizes the industry, allows to increase the number of farms for breeding horses, and to develop scientific developments in biotechnology and reproduction of these animals.
\end{abstract}

Keywords: stallions, phantom, mare, artificial vagina, semen, diluent, packaging, labeling, cryopreservation 


\section{Introduction}

Horse breeding in Ukraine has always been an industry of national importance, the functional orientation of which has changed because of the development of socio-economic relations. In the conditions of reforming the agro-industrial complex and transition to a market economy, the development of horse breeding will contribute to the improvement of economic spheres. Currently, the role and importance of horses in state farms has a complex nature. Horse breeding is used to improve existing and create new, more advanced breeds that would meet the requirements of European and world standards (Atroschenko, 2008; Vasileva, 2007). First successful cryopreservation was carried out in the early 20th century using bull semen, and the first effective insemination using frozen stallion semen was performed in the United States of America in 1957 when the semen was taken from the epididymis of the stallion (Gopka, Homenko, \& Pavlenko, 2004).

\section{Analysis of recent researches and publications}

In the modern practice of horse breeding, obtaining sperm by an artificial vagina for cryopreservation, or insemination with fresh (native) or freshly diluted sperm is a common practice. In recent years, various countries have accumulated considerable experience in working with freshly diluted cooled sperm, developed methods of cryopreservation, which contribute to maintaining high fertility of sperm. Several technologies for cryopreservation of stallion sperm have been developed and are constantly used. Each of them includes many stages that affect the quantitative and qualitative indicators of sperm (Nevzorova, 2011).
The use of frozen sperm allows to determine the timing of insemination, because sperm can be sent at any time before ovulation, and therefore available for insemination at the optimal time (Gopka, Homenko, \& Pavlenko, 2004). It also allows avoiding bacterial contamination of sperm during natural mating, which leads to embryonic mortality, decreasing impregnation capacity during subsequent sexual cycles, and the birth of weak or non-viable offspring (Deyaki putannya rozvutky kinnoi galyzi, 2010). Existing ways of sperm freezing differ significantly in technological methods, in methods of preparation for cryopreservation, solvents and media, freezing techniques, method of storage, defrosting, and using (Nevzorova, 2011).

Nowadays interest in horse breeding is growing. This is evidenced by scientific publications of many scientists, laws, and orders on the reorganization of the industry, the creation of new horse farms (Pro stvorennya derzhavnoi ystanovu "Derzhavna durekcia z ypravlinnya, kontrolyu ta rozvutky konyarstva Ukrainu, 2010; https://ec.europa.eu/food/animals/ semen/equine_en). At the same time, due to the development of the private sector of the economy, the need for horses not only for work but also for sports, in order to meet the aesthetic and cultural needs of the population has increased.

Currently, there is only one certified horse semen collection center in Ukraine (https://www.pilchuckvet.com/articles/ freezing-stallion-semen). This number is due to insufficient logistical and scientific support of the industry, which inhibits the realization of the productive potential of this species of animals and still remains unresolved. Therefore, this issue is relevant to both practitioners and scientists.

The purpose of the study is to develop an algorithm for work with sperm of a stal- 
lion of Belgian sport breed, to get acquainted with the newest methods for selection and cryopreservation of stallion sperm.

\section{Materials and methods of research}

The research was conducted at the Zhashkiv Equestrian School, during 2020 with 5 clinically healthy stallions of the Belgian sport breed at age from 15 to 19 years.

Collection of material (sperm) was conducted on an artificial vagina "Hannover" using a phantom of the same company twice a week, in compliance with all sanitary requirements, in the morning before feeding the animals. Sperm were macroscopically evaluated for volume, color, odor, and impurities. Microscopic evaluation included determination of the number of living, dead and pathological forms of sperm cells (using automatic software from Minitube), concentration (using the device SpermaCue from the same company). Testing the activity of sperm was performed in the "crushed drop" preparation in compliance with all requirements. INV 96 and INRA Freeze from IMV Technologies were used to thin the sperm, and Maxifreeze medium was used to protect the sperm from the stress of centrifugation. For marking straws an automatic printer EasyCoder for straws of 0.5 and $0.25 \mathrm{ml}$ from Minitube was used. Sperm packing into straws was performed using an automatic packing machine MPP Uno, and the process of freezing semen using a Computer controlled rate freezer $14 \mathrm{~S}$ and software from Minitube.

\section{Results of the research and their discussion}

Today there is only one licensed cryogenic sperm bank of certified sports stallions in Ukraine, which is located in Zhashkiv Equestrian School. From that School, sperm is transported abroad (https://www.pilchuckvet.com/articles/ freezing-stallion-semen). It contributes to the improvement of the existing gene pool of horses in our country and promotes the industry.

One portion of ejaculate from an artificial vagina can inseminate several mares. This minimizes the spread of diseases and allows to store sperm in liquid nitrogen at a temperature of $196{ }^{\circ} \mathrm{C}$ for a long time, and the sperm bank will allow you to store sperm of highly breeding offspring and at any time to have access to the best stallions or to sell semen abroad.

Algorithm for working with stallion semen:

1. Collection of ejaculate.

2. Evaluation of ejaculate quality:

- macroscopic;

- microscopic.

3. Determining the number of sperm.

- requirements for native;

- requirements for frozen.

4. Dilution:

- sperm dilution medium;

- description of the process.

5. Packing semen into straws (volume $0.5 \mathrm{ml})$.

6. Freezing (cryopreservation) of sperm:

- requirements;

- description of the process.

\section{Storage.}

The protocol specifies the main collection parameters (date, time, nickname, number of mounts, number of jumps, use of a phantom or false animal), ejaculate volume, color, odor, mucus, concentration, sperm activity, pathological forms, used solvents for sperm. The protocol also, indicates the number of doses that can be made from this ejaculate, the number of ready doses and straws with semen, and storage location. 


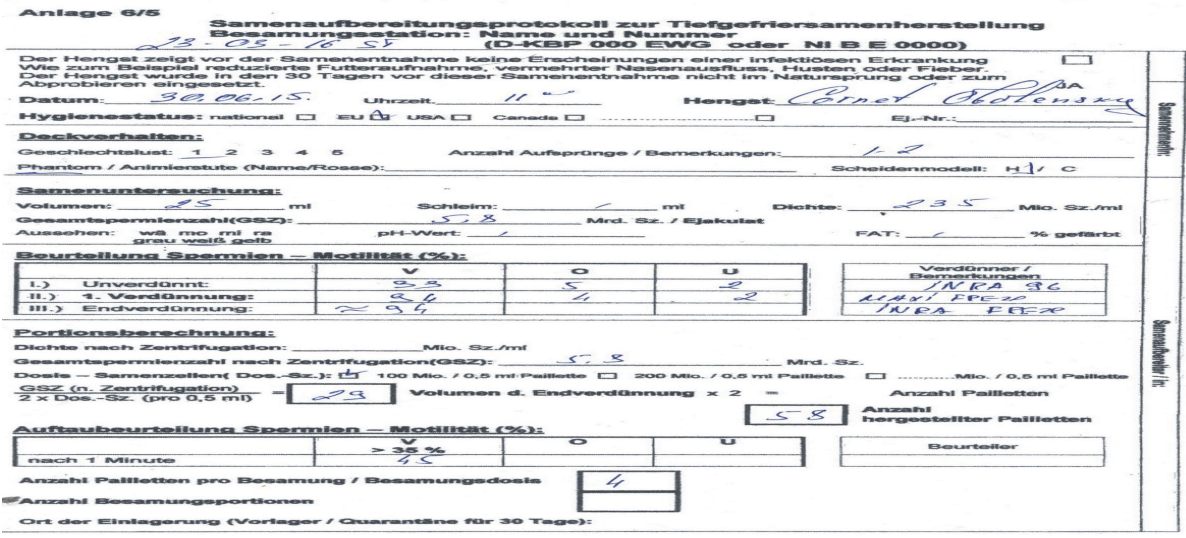

Fig. 1. Cartogram of the humus content of the field with the content of physical clay $45-50 \%$

The School provides each buyer with a freeze report, which shows the data on the stallion's semen (Fig. 2).

According to the protocol, a study was conducted on the collection, evaluation, and cryopreservation of stallion sperm. The first stage was the collection of semen from stallions.
Stage 1. Collection is carried out twice a week, in compliance with all sanitary requirements, in the morning before feeding the animals in the arena, which is well lit, the walls are made of a material that is easy to clean and disinfect, the room is equipped with a phantom for a stallion, model Hannover,

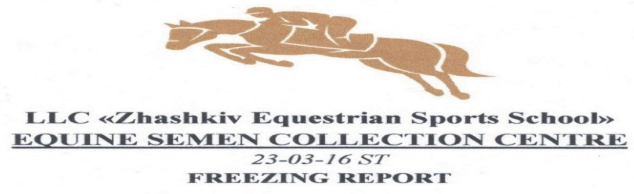

STAYLION:
RASSE:
Age at the time of testing:
LIFE No:

CORNET OBOLENSKY

Belgian (BWP)

19 years

O56-002-WoO1 84083

LIFE No:

$0103,2018-10.102018$

\begin{tabular}{|c|c|}
\hline Parameters fresh semen & \\
\hline Average number of vaginal leaps: & $1-2$ \\
\hline Average volume of filtered semen (in $\mathrm{ml}$ ): & 30 \\
\hline Average concentration (in million of $\mathrm{spz} / \mathrm{ml}$ ): & 200 \\
\hline Total number of spermatozoa per ejaculate (in milliards): & 6,0 \\
\hline Total morphologic normal (\%): & $91 \%$ \\
\hline \multicolumn{2}{|l|}{ Parameters freezing semen } \\
\hline Number of frozen ejaculates: & 42 \\
\hline Average number of straws produced by ejaculate canned: & $32-40$ \\
\hline Average number of doses produced by ejaculate canned: & $4-7$ \\
\hline \multirow{2}{*}{$\begin{array}{l}\text { Quality of semen when defrosted (\% of motile spermatozOa): } \\
\text { AVERAGE CONGELATION(M/min)/VELOCITY Mic/sce } \% \text { PROGRESSIVE MOT: }\end{array}$} & 74 \\
\hline & $365 / 50 / 43$ \\
\hline Number of ejaculation canned: & 42 \\
\hline Color of straws: & grey \\
\hline
\end{tabular}

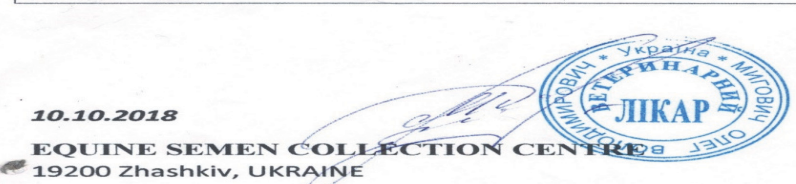

Dr. O.Migovich

EQUINE SEMEN COIL
19200 Zhashkiv, UKRAINE

Fig. 2. Sperm Freeze Report 


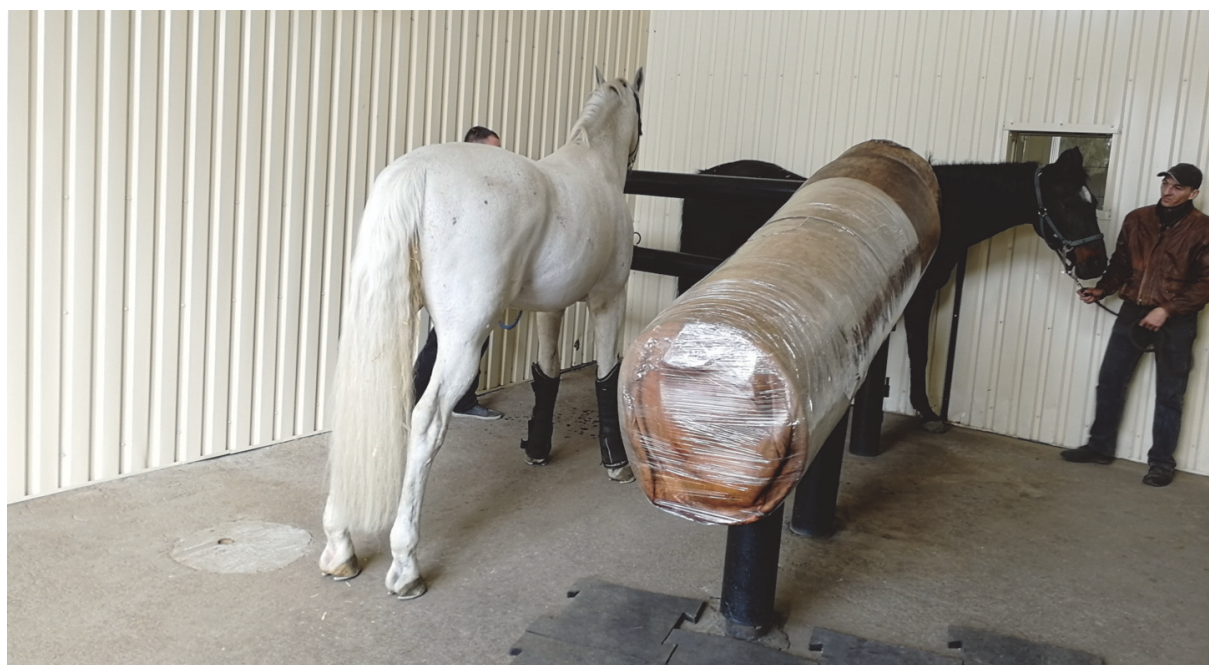

Fig. 3. Phantom for collecting sperm from a stallion

which is covered with a special layer before each mount to prevent contamination by microorganisms (Fig. 3).

The floor around the phantom is covered with special rubber mats in order to prevent injuries. To stimulate a clear manifestation of the male's sex- ual reflexes, during sperm collection, there is a mare in heat behind the barrier (Fig. 4).

The arena is equipped with a special window to the laboratory for the transfer of ejaculate for further evaluation. The artificial vagina Hannover from Mini-

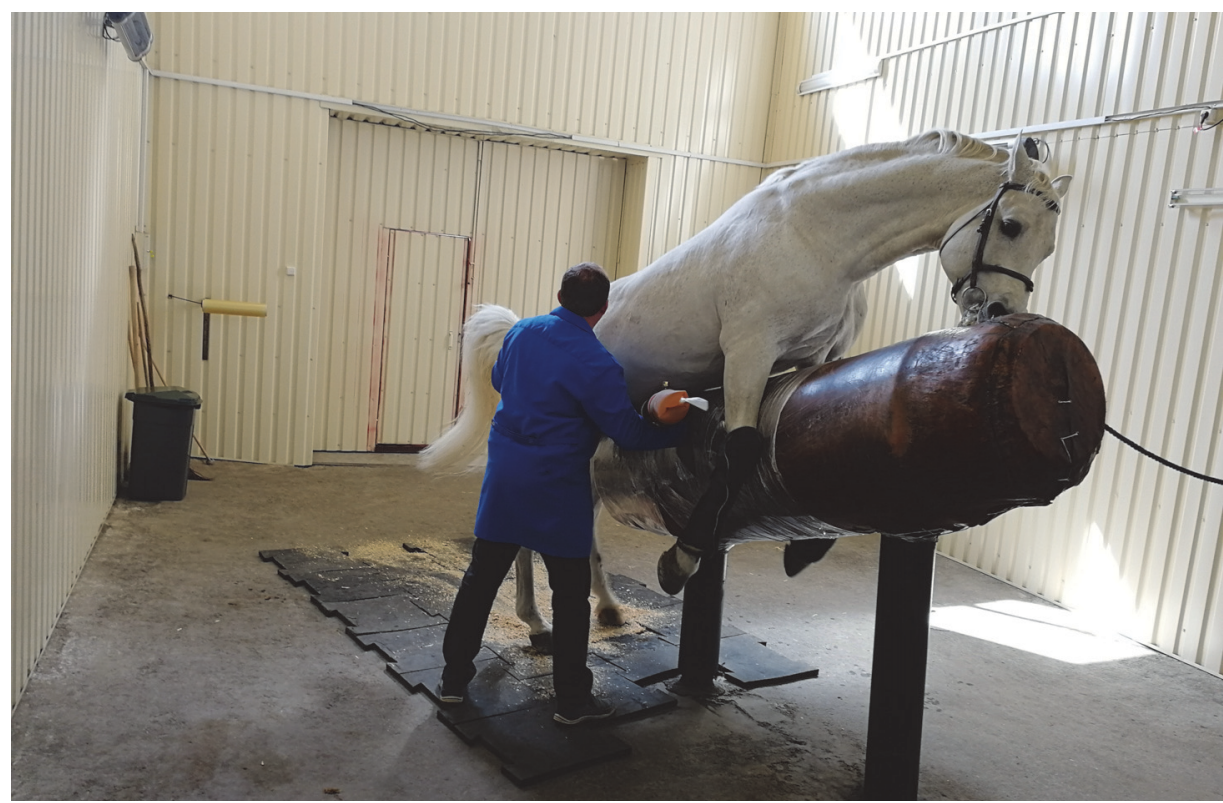

Fig. 4. Sperm collection 
tube is used for collecting sperm which consists of a small valve, an inner cover, rubber rings, and a leather handle.

Before collection, the artificial vagina is pre-disinfected, heated with water to a temperature of $55^{\circ} \mathrm{C}$, and at the time of taking it should be $40-42{ }^{\circ} \mathrm{C}$. A sterile, vaseline-lubricated plastic bag is placed on the prepared artificial vagina, which is tied at the exit end (serves as a sperm collector). The bandaged end is cut after collection, and the semen is transferred to a special filtering vial that separates the semen from the secrets of the vesicles (Fig. 5).

Stage 2. The laboratory assistant conducts the evaluation of the obtained ejaculate, which includes organoleptic evaluation: volume, color, odor, the presence of impurities; microscopic: motility, density, concentration, pathological forms of spermatozoa. Macroscopic evaluation of ejaculate is performed after semen filtration from the secrets of the vesicles in a graduated vessel for filtering the semen of the stallion.

Microscopic evaluation of sperm. Sperm motility is determined in the "crushed drop" preparation simultaneously with the determination of sperm density. Then the concentration of semen is determined using a device SpermaCue (Minitube). Determination of live, dead, and pathological forms of spermatozoa is carried out using automatic software from Minitube.

Stage 3. Calculation of the number of sperm doses according to the formula:

$\frac{\text { GSZ (N.Z.) }}{2 \text { XDos.-Sz. }(\text { pro } 0.5 \mathrm{ml})}=29$ V. d. E. $\times 2=58$

V. d. E. $\times 2=58$ A. S.,

where: GSZ (N. Z.) - concentration of semen in the ejaculate for centrifugation;

Dos.-Sz. (pro $0.5 \mathrm{ml}$ ) - sperm dose (100 million in straws $0.5 \mathrm{ml}$ );

V. d. E. - volume of the final dilution;

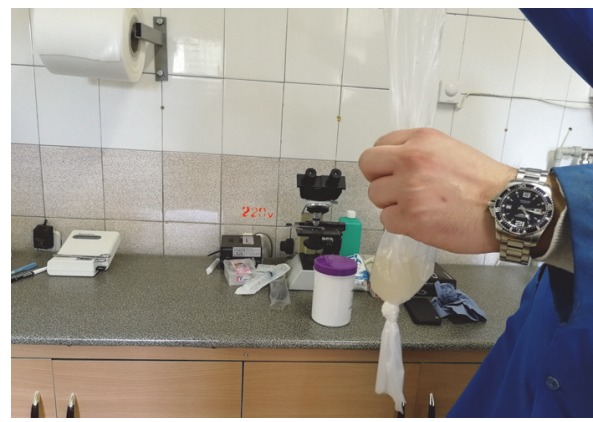

Fig. 5. Obtained ejaculate

A. S. - number of straws (in our case 58) (Fig. 1).

Requirements for sperm of stallions for artificial insemination (European standard):

fresh semen: at least 300 million spermatozoa with rectilinear translational motion;

cooled semen (diluted / fresh):

- at least 300 million spermatozoa with a rectilinear translational motion at the time of breeding.

- spermatozoa with rectilinear translational motion at the time of insemination not less than $35 \%$.

Diluted semen and semen intended for transportation:

- dose of sperm: at least 600 million spermatozoa with rectilinear translational motion during dilution;

- spermatozoa with rectilinear translational motion at the time of insemination not less than $35 \%$.

Frozen semen:

- dose of sperm: at least $35 \%$ of spermatozoa with rectilinear translational motion after thawing;

- at least 250 million spermatozoa with rectilinear translational motion per dose for artificial insemination after thawing.

Stage 4. Dilution of stallion semen:

solvent for sperm INRA 96 in a dose of $1: 1$ and INRA Freeze is added to the freshly obtained material (Fig. 6); mixing thoroughly with smooth movements; 

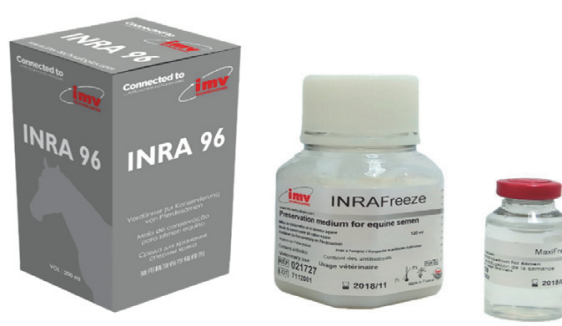

Fig. 6. Solvent for stallion semen

adding $4 \mathrm{ml}$ of Maxifreeze medium, which protects sperm from centrifugal stress;

centrifugation of ejaculate at 2800 rpm for 20 minutes.

After the sperm deposition procedure, the maximum amount of supernatant (solvent and sperm plasma) is taken.

Step 5. Packing semen into straws (capacity $0.5 \mathrm{ml}$ ) using a packaging machine from Minitube MPP Uno. The date of semen collection and the stallion's number are indicated on the sequin. Straws are labeled with an EasyCoder automatic printer.

Step 6. Cryopreservation: semen for pre-cooling is placed in a refrigerator at a temperature of $+4{ }^{\circ} \mathrm{C}$ on a special plate for 2.5 hours. After that, the straws are moved to the Computer controlled rate freezer $14 \mathrm{~S}$, which has specially adapted software from Minitube for quick freezing of stallions. The duration of freezing in this device is 7 minutes to a temperature of $-120^{\circ} \mathrm{C}$. One dose of semen must be thawed and evaluated according to the protocol parameters.

Step 7. After rapid freezing, the semen for long-term storage is transferred to a cryogenic storage Dewar (temperature $-196^{\circ} \mathrm{C}$ ) and stored for 60 days in quarantine. Then, the semen is transferred to a storage room in cryogenic storage Dewar.
Thus, following the above rules of selection, evaluation, calculation, dilution, packaging, cryopreservation, and storage of sperm of high-value stallions can increase the number of sperm banks. This promotes the industry, allows to increase the number of farms for horse breeding, and to develop scientific developments in biotechnology and reproduction of these animals.

\section{Conclusions and future perspectives}

The algorithm for manipulation with the semen of stallions according to the European protocol is developed.

Cryopreservation using pre-cooling of sperm for $2.5 \mathrm{~h}$ and subsequent rapid freezing in liquid nitrogen vapor is an effective method to preserve the fertilizing ability of stallion semen.

Increasing the number of sperm banks of high-value stallions promotes this industry and will increase the number of farms for these animals breeding.

\section{References}

Atroschenko, M. M. (2008). Kilkisnui i vudovui sklad mikroorganizmiv, vudilenuh iz spermu zherebciv-virobnukiv, yaki vukorustovyytsya $v$ rychnomy osimeninni. Konyarstvo I kinnui sport, 5:5-7. (in Ukrainian)

Cryoprotectors and cryopreservation of horse sperm: an overview of industrial cryoprotectors and the effect of cryopreservation on horse sperm membranes. Electronic resource]. - Access mode: https://medcraveonline.com/ JDVAR/cryoprotectants-amp-cryopreservation-of-equine-semen-a-reviewof-industry-cryoprotectants-and-the-effects-of-cryopreservation-on-equine-semen-membranes.html 
Cryopreservation of stallion sperm using various cryoprotectors and combinations of cryoprotectors. [Electronic resource]. - Access mode: https://pubmed.ncbi.nlm.nih. gov/26573763/

Efficiency of cryopreservation of stallion sperm. [Electronic resource]. - Access mode: https://www.mdpi.com/20762615/10/6/1033/pdf

Deyaki putannya rozvutky kinnoi galyzi [Some issues of horse breeding development]. Nakaz ministerstva agrarnoi polituku Ukrainu. № 510 (2010). (in Ukrainian)

Goncharenko, I. V. \& Platonova, N. P. (2012). Use of technological methods of freezing and thawing stallion sperm in small volumes. Scientific bulletin "Askania Nova", 5(1):227-236.

Vasileva, O. V. (2007). Sravnitel’ny`j analiz otechestvenny`kh i zarubezhny`kh podkhodov $\mathrm{k}$ probleme zamorazhivaniya spermy' zherebczov [Comparative analysis of domestic and foreign approaches to the problem of freezing the semen of stallions]. (Master's thesis). Duvovo. (in Russian)Gopka, B. M., Homenko, M. P., \& Pavlenko,
P. M. (2004). Konyarstvo [Horse breeding]. K.: Vuscha osvita, 435. (in Ukrainian)

Nevzorova, L. (2011). Levadu i shelter, 24. (in Ukrainian)

Pro stvorennya derzhavnoi ystanovu "Derzhavna durekcia z ypravlinnya, kontrolyu ta rozvutky konyarstva Ukrainu" [About creation of the state institution "State directorate on management, control and development of horse breeding of Ukraine"]. Nakaz ministerstva agrarnoi polituku Ukrainu. № 185 (2010). (in Ukrainian)Cryopreservation of equine spermatozoa. Available at: _2020

Equine. Available at: https://ec.europa.eu/ food/animals/semen/equine_en_2019

Vasilyeva, O. V.(2007). Comparative analysis of domestic and foreign approaches to the problem of freezing the sperm of stallions: abstract of the dissertation for the study of scientists. the steppe. candidate Biol. 03.00.13 «Physiology». Amazing, 36. (in Russian)

Field results in France (1985-2005) on factors affecting the fertility of frozen stallion sperm. [Electronic resource]. - Access mode: https:// pubmed.ncbi.nlm.nih.gov/16112529/

\section{О. В. Мигович, Ю. С. Масалович, О. А. Вальчук (2020). ОСОБЛИВОСТІ ВІДБОРУ ТА КРІОКОНСЕРВАЦІї СПЕРМИ ЖЕРЕБЦІВ. Ukrainian Journal of Veterinary} Sciences, 11(3): 102-110, https://doi.org/10.31548/ujvs2020.03.011

Анотація. Конярство в Україні завжди було галуззю загальнодержавного значення, функціональна спрямованість якої змінювалась в залежності від розвитку соціально-економічних відносин. Нині роль і значення коней у господарствах держави має комплексний характер. Племінних коней використовують для поліпшення існуючих та створення нових, більш досконалих порід, які б відповідали вимогам європейських і світових стандартів.

Підвищення ефективності технологій відтворення у конярстві і подальший прогрес порід неможливі без втілення методів итучного осіменіння коней, в тому числі кріоконсервації сперми.

За останні 10 років було досягнуто багатократних покращень щодо зберігання та переробки замороженої сперми жеребців, використання альтернативних кріопротекторів та нових комерційних розширювачів, які забезпечують кращий захист клітин під час заморожування. 
Проаналізовано, що в Україні єлише один ліцензований кріогенний банк сперми сертифікованих спортивних жеребців, який знаходиться в Жашківській кінно-спортивній школі, звідти транспортують сперму за кордон. Він сприяє покращенню існуючого генофонду коней у нашій державі та сприяє популяризачії даної галузі. Досліджено технологічний прочес відбору та кріоконсервації сперми племінних жеребців Бельгійської спортивної породи в Жашківській кінно-спортивній школі Черкаської області. Ознайомлено з новітніми методами відбору та кріоконсервації сперми жеребців. Досліджено, що кріоконсервація з використанням попереднього охолодження сперми впродовж 2,5 год та з подальшим швидким замороженням у парах рідкого азоту є ефективним методом для збереження запліднюючої здатності сперми жеребців. Встановлено, якщо дотримуватись цих правил відбору, оцінки, розрахунку, розведення, пакування, кріоконсервації та зберігання сперми високоцінних жеребців, то можна збільшувати кількість банків сперми. Це популяризує дану галузь, дає змогу збільшити кількість господарств з розведення коней та розвивати наукові розробки з біотехнології та репродуктології цих тварин.

Ключові слова: жеребці, Фантом Маре, итучна вагіна, сперма, розріджувач, пакування, маркування, кріоконсервація 